\title{
The Effectiveness of Hydroxychloroquine Versus Hydroxychloroquine Plus Lopinavir/Ritonavir Therapy in SARS- CoV-2 Pneumonia
}

\author{
SARS-CoV-2 Pnömonisinde Hidroksiklorokin ile Hidroksiklorokin Artı Lopinavir/Ritonavir \\ Tedavisinin Etkinliği
}

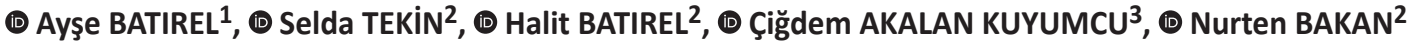 \\ 1 University of Health Sciences Turkey, Kartal Dr. Lütfi Kırdar City Hospital, Clinic of Infectious Diseases and Clinical Microbiology, Istanbul, Turkey \\ 2Sancaktepe Şehit Prof. Dr. Illhan Varank Training and Research Hospital; Çekmeköy State Hospital, Clinic of Anesthesiology and Reanimation, \\ istanbul, Turkey \\ ${ }^{3}$ Sancaktepe Şehit Prof. Dr. Illhan Varank Training and Research Hospital; Çekmeköy State Hospital, Clinic of Infectious Diseases and Clinical \\ Microbiology, istanbul, Turkey
}

\section{Abstract}

Introduction: There is no specific antiviral treatment with proven efficacy and safety in the management of Coronavirus disease-2019 (COVID-19). We aimed to compare the effectiveness of hydroxychloroquine (HO) monotherapy and HQ-lopinavir/ritonavir (Lpv/r) combined therapy in patients with laboratory-confirmed COVID-19 and to determine the independent factors predicting mortality.

Materials and Methods: Retrospective observational multi-centered cohort study.

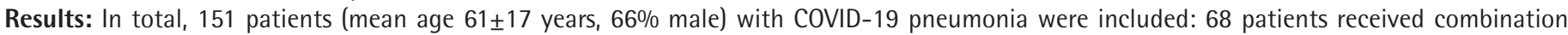
therapy, i.e., Lpv/r in addition to $\mathrm{HO}$, and 83 patients received only $\mathrm{HO}$. The patients in both groups were similar regarding the majority of baseline variables except for white blood cell count, procalcitonin, lactate dehydrogenase levels, intensive care unit (ICU) admission rates, which were significantly higher, and decreased oxygen saturation in the combination group. The mean duration of symptoms and hospital stay were $5.6 \pm 2.3$ days and $12.7 \pm 9.4$ days, respectively. Nearly $43 \%(n=65)$ of patients were admitted to the ICU. Patients in the HO monotherapy group had a shorter stay in hospital than those in the combination group (10 vs. 16 days, $p<0.005$ ). The primary end points were $14-$ and 28-day mortality. Neither treatment group revealed significant differences with respect to 14-day and 28-day survival before and after propensity score matching. Age, hypertension, diabetes mellitus, chronic obstructive pulmonary disease, the Charlson Comorbidity Index (CCI), and ICU stay length were variable predictors of 14-day mortality, while CCI [Hazard ratio (HR) 95\% confidence interval (CI): 0.85 (0.43-0.9)] and ICU stay length [HR (95\% Cl): 1.5 (1.39-1.76)] were the independent predictors of 28-day mortality.

Conclusion: Combination therapy with Lpv/r and HO did not provide any benefit compared with HO monotherapy. Charlson Comorbidity Index and ICU stay were independent predictors of 28-day mortality.

Keywords: SARS-CoV 2, COVID-19, treatment, hydroxychloroquine, lopinavir/ritonavir

\section{Öz}

Giriş: Koronavirüs hastalığı-2019'un (COVID-19) yönetiminde etkinliği ve güvenliği kanıtlanmış spesifik bir antiviral tedavi yoktur. Laboratuvarca doğrulanmış COVID-19 hastalarında hidroksiklorokin monoterapisi ile hidroksiklorokin-lopinavir/ritonavir (Lpv/r) kombine tedavisinin etkinliğini karşılaştırmayı ve mortaliteyi öngören bağımsız faktörleri belirlemeyi amaçladık.

Gereç ve Yöntem: Geriye dönük gözlemsel çok merkezli kohort çalışmasıdır.

Cite this article as: Batırel A, Tekin S, Batırel H, Akalan Kuyumcu Ç, Bakan N. The Effectiveness of Hydroxychloroquine Versus Hydroxychloroquine Plus Lopinavir/ Ritonavir Therapy in SARS-CoV-2 Pneumonia. Mediterr J Infect Microb Antimicrob. 2021;10:8. 
Bulgular: Toplamda, COVID-19 pnömonili 151 hasta (ortalama yaş $61 \pm 17$ yıl, \%66'sı erkek) dahil edildi. Altmış sekiz hasta kombinasyon tedavisi (hidroksiklorokine ek olarak Lpv/r), 83 hasta sadece hidroksiklorokin aldı. Her iki gruptaki hastalar; lökosit sayısı, prokalsitonin, laktat dehidrojenaz seviyeleri, yoğun bakım ünitesine (YBÜ) yatış oranları haricinde (kombinasyon grubunda önemli ölçüde daha fazla artmış ve oksijen satürasyonu

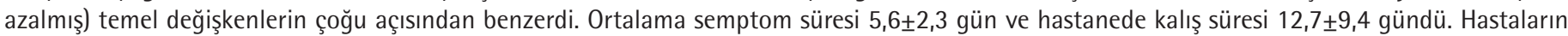
yaklaşık \%43'ü $(n=65)$ YBÜ'ye yatırıldı. Hidroksiklorokin monoterapi grubundaki hastaların hastanede kalış süresi kombinasyon grubuna göre daha kısaydı (10'a karşı 16 gün, p<0,005). Primer sonlanım noktaları 14 ve 28 günlük mortaliteydi. Eğilim skoru eşleştirmesi öncesi ve sonrasında her iki tedavi grubu arasında anlamlı farklılık gözlenmedi. Yaş, hipertansiyon, diabetes mellitus, kronik obstrüktif akciğer hastalığı, Charlson Komorbidite İndeksi (CCI) ve YBÜ'de kalış 14 günlük mortaliteyi öngören değişkenler iken, $\mathrm{CCl}$ [Hazard oranı (HR) [\%95 güven aralığı (CI): 0,85 (0,43-0,9)] ve YBÜ'de kalış [HR (\%95 Cl): 1,5 (1,39-1,76)], 28 günlük mortalitenin bağımsız prediktörleri idi.

Sonuç: Lpv/r ve hidroksiklorokin ile kombinasyon tedavisi, hidroksiklorokin monoterapisine kıyasla herhangi bir fayda sağlamadı. Charlson Komorbidite İndeksi ve YBÜ'de kalış, 28 günlük mortalitenin bağımsız belirleyicileriydi.

Anahtar Kelimeler: SARS-CoV-2, COVID-19, tedavi, hidroksiklorokin, lopinavir/ritonavir

\section{Introduction}

As of October 27, nearly 44 million cases of Coronavirus disease-2019 (COVID-19) patients infected with Severe Acute Respiratory Syndrome Coronavirus-2 (SARS-CoV-2) and over $1,170,000$ deaths had been reported world wide in the global pandemic ${ }^{[1]}$. Thousands of new cases are detected in many countries every day. The first COVID-19 case in our country was confirmed on March 11, 2020. There is no specific antiviral treatment with proven efficacy and safety inthemanagement of COVID-19 disease ${ }^{[2]}$, but more than 150 phase 3-4 randomized controlled trials in adults are currently underway in this area because of the urgent need for an effective treatment. Potential treatment options include off-label use of the antimalarial drugs chloroquine and hydroxychloroquine (HO) as "viral entry inhibitors", the antiviral drugs lopinavir/ritonavir (Lpv/r) as "viral protein synthesis inhibitors", favipravir and remdesivir as "viral RNA polymerase /RNA synthesis inhibitors", which have been repositioned for COVID-19 therapy, and convalescent-phase immune plasma ${ }^{[3-7]}$. HO sulfate inhibits SARS-CoV-2 in vitro ${ }^{[8]}$. Lopinavir/r is a combination of two human immunodeficiency virus (HIV)-1 protease inhibitors widely used in the treatment of HIV infection with a good safety profile. It binds to the SARS-CoV 3C-like protease and inhibits viral protein synthesis ${ }^{[9]}$. Lopinavir, an HIV protease inhibitor, has been shown to have invitro activity against SARS-CoV-2 ${ }^{[10,11]}$. Moreover, it has been reported to have activity against Middle East Respiratory Syndrome (MERS-CoV-2) in vitro ${ }^{[12]}$ and in animal models ${ }^{[13]}$. Related to the efficacy of $L p v / r$ treatment, various data, including both in vitro and clinical study results, are available in the medical literature ${ }^{[14,15]}$. A randomized trial with LPV/r including 199 severe COVID-19 patients has shown that it confers no advantage beyond standard care alone ${ }^{[16]}$. A statistically non-significant decrease in mortality was observed in the LPV/r-added arm (19\% vs. 25\%). Lopinavir/r (400 mg/100 $\mathrm{mg}$ bid) and interferon-alpha ( 5 million $U$ bid) are recommended as antiviral therapy under Chinese guidelines ${ }^{[17]}$. Because of the knowledge gap, the Infectious Diseases Society of America
(IDSA) guidelines recommend Lpv/r for patients admitted to the hospital with COVID-19 only within a clinical trial ${ }^{[18]}$.

A COVID-19 management guideline prepared by the Scientific Committee of the Ministry of Health in our country has been updated frequently as the related knowledge in the literature increases $^{[19]}$. In the version of this guide dated February 25, 2020, firstly, HQ $200 \mathrm{mg}$ tb (2x1) (for five days) was recommended in mild COVID-19 cases, while Lpv/r (400 mg/100 mg bid) (for 10-14 days) was recommended primarily in severe cases. In the next version of the same guide dated March 25, 2020, HO 200 mg tablets (2x1 after 2x2 loading, for five days) and Lpv/r (400 $\mathrm{mg} / 100 \mathrm{mg}$ tablets bid for 10-14 days) were recommended in probable or definitive COVID-19 cases with pneumonia and in patients with a severe course and initial therapy failure, respectively.

In the subsequent guide, dated April 2, 2020, the use of Lpv/r (for 10-14 days) +/- HO (for five days) was the recommended treatment protocol in pregnant women with COVID-19. All the drugs available in our country have been delivered to hospitals for treatment of COVID-19 patients by the Ministry of Health. Since no specific proven antiviral treatment is available, the combined use of possible treatment options in COVID-19 patients should be considered on a patient basis and by evaluating all currently available literature. In this study, we primarily aimed to compare the effectiveness of $\mathrm{HO}$ monotherapy and HQLpv/r combined therapy in patients diagnosed with COVID-19. Secondarily, we aimed to determine the independent factors predicting mortality.

\section{Materials and Methods}

Hospitalized COVID-19 patients older than 18 years whose diagnoses were confirmed by the reverse transcriptasepolymerase chain reaction (RT-PCR) method and who received either HO monotherapy or HQ-Lpv/r combined therapy, followed-up in pandemic clinics of University of Health Sciences Turkey, Kartal Dr. Lütfi Kırdar City Hospital, Sancaktepe Şehit Prof. Dr. İlhan Varank Training and Research Hospital and 
Çekmeköy State Hospitals between March 11, 2020 and April 30, 2020, were included in this study. Demographic features [age, gender, underlying diseases, Charlson Comorbidity Index (CCI)] ${ }^{[20]}$, clinical and laboratory data, vital signs, treatment schemes, side effects, and outcome measures were obtained from patient records or hospital databases. The laboratory data for patients in two treatment groups were recorded on the first, third, and seventh treatment days. The first group included only patients receiving $\mathrm{HO}$ monotherapy, and the second group included patients receiving $\mathrm{HO}-\mathrm{Lpv} / \mathrm{r}$ combined therapy. The dosing regimes of adjuvant drugs were the same in both groups. The efficacy of the treatment protocols in both groups were evaluated by comparing the clinical outcomes, defined as discharge from the hospital or in-hospital mortality, and independent factors affecting mortality were determined. HIV infection was ruled out in all patients with negative $4^{\text {th }}$ generation enzyme linked immunosorbent assay test results. Electrocardiographic monitoring of patients was performed for any prolongation of the QTc and/or PR interval on the first day in hospital and every other day until discharge. All co-administered medications were checked for any drug-drug interactions.

The primary endpoints were 14-day and 28-day survival, and the secondary endpoints were clinical outcomes and improvement in laboratory parameters.

Upper respiratory tract swab samples were studied byreal-time RT-PCR (Roche Light Cycler 96) to confirm the diagnosis of COVID-19. Only patients with a laboratory-confirmed COVID-19 diagnosis were included in the study. This retrospective study was approved by the institutional review board of University of Health Sciences Turkey, Kartal Dr. Lütfi Kırdar City Hospital on May 13, 2020 with number 2020/514/177/2 and was conducted in compliance with the Declaration of Helsinki Principles.

\section{Statistical Analysis}

Statistical Package for the Social Sciences (SPSS) Statistics, version 17.0 (Chicago: SPSS Inc.) was used for all statistical analyses. Mean, standard deviation, and frequencies were used for descriptive statistics, $\chi^{2}$ test or Fisher's exact tests were used to analyze categorical variables, and the Student's t-test was used to test for the statistical significance of differences between continuous variables. Cox regression analysis and Kaplan-Meier survival analysis were used to determine the independent predictors of mortality. Results were evaluated as odds ratios and 95\% confidence intervals. A two-sided $p$ value $<0.05$ was considered to indicate statistical significance. In order to adjust for selection bias, propensity score matching (PSM) was performed. The propensity score (PS) was estimated by multinomial logistic regression, which included all of the treatment-related prognostic factors. Patients who had similar PS in the two groups were matched by using the "nearest neighbor matching method". The patients with either PS $<0.3$ or PS $>0.6$ were excluded from the groups for matching. After PSM, the groups were characterized similarly in terms of risk factors. The statistical analysis was repeated after PSM. A $p$ value $<0.05$ was considered to indicate a statistically significant result.

\section{Results}

In total, 151 patients were included in this study. The test group $(n=68)$ comprised the patients who received combination therapy (i.e., $L p v / r$ in addition to standard care consisting of $\mathrm{HO})$, while the patients in the control group $(n=83)$ were only treated with standard care $(\mathrm{HO})$. None of the patients received dexamethasone as it was not recommended in the guidelines at the beginning of the pandemic. The mean age of the patients was 61 (minimum: 21, maximum: 100) years. Most of the patients $(66 \%)$ were male. All of the patients had thorax computed tomography findings compatible with COVID-19 pneumonia. Baseline demographic features, laboratory values, and outcomes of patients receiving two different treatment regimens are summarized in Table 1. Patients in both groups were similar regarding the majority of those variables except for baseline white blood cell (WBC) count, procalcitonin (PCT), lactate dehydrogenase (LDH) levels, and intensive care unit (ICU) admission rates, which were significantly higher in the combination therapy group. Initial oxygen saturation rates were lower in the combination group. Hypertension (42\%) and diabetes mellitus (DM) (30\%) were the most common comorbid diseases. Sixteen percent of patients had chronic renal disease, and 2.6\% had chronic renal failure. The mean duration of symptoms and hospital stay were $5.6 \pm 2.3$ days and $12.7 \pm 9.4$ days, respectively. Treatment was initiated within five to six days of symptom onset. Nearly $43 \%(n=65)$ of patients $(2 / 3$ in the combination treatment group) were admitted to the ICU during follow-up for COVID-19. Patients in the HO monotherapy group had a shorter stay in hospital than those in the combination therapy group (10 vs. 16 days, $p<0.005$ ). Leukocyte counts, creatinine, C-reactive protein (CRP), PCT, LDH, ferritin, and D-dimer levels onthe $3^{\text {rd }}$ and $7^{\text {th }}$ days of therapy were significantly higher, but oxygen saturation was lower in the combination therapy group (Figures 1-5). Six patients had adverse events (1 nauseavomiting, 1 hyponatremia, 1 hypokalemia, 1 hyperkalemia, 1 elevated transaminase levels) in the monotherapy group, and six patients in the combination therapy group faced adverse events (2 nausea-vomiting, 1 diarrhea, 3 hypokalemia, 1 hyperkalemia, 1 elevated transaminase levels). No serious adverse events (such as prolonged QTc, hepatotoxicity etc.) causing early cessation of therapy occurred in either group. Complications were observed in 22 patients (27\%) in the monotherapy group [3 pulmonary thromboembolism (PTE), 19 hepatitis, 1 secondary bacterial infection as pneumonia]. In the combination 
Table 1. Baseline demographic features, laboratory values, and outcomes of patients on two different treatment regimens

\begin{tabular}{|c|c|c|c|}
\hline Characteristic/variable & $\begin{array}{l}\text { Standard } \\
\text { care } \\
(n=83)\end{array}$ & $\begin{array}{l}\text { Standard } \\
\text { care+lopinavir/ } \\
\text { ritonavir } \\
(\mathrm{n}=68)\end{array}$ & $p$ value \\
\hline Age (years), median (IOR) & $58(34)$ & 64 (33) & 0.721 \\
\hline Gender (male) $(n, \%)$ & $50(60)$ & $51(75)$ & 0.55 \\
\hline $\begin{array}{l}\text { Fever }(n, \%) \\
\text { Cough }(n, \%) \\
\text { Dyspnea }(n, \%)\end{array}$ & $\begin{array}{l}53(64) \\
69(83) \\
52(63) \\
\end{array}$ & $\begin{array}{l}45(66) \\
61(89) \\
46(68)\end{array}$ & $\begin{array}{l}0.766 \\
0.245 \\
0.522 \\
\end{array}$ \\
\hline $\begin{array}{l}\mathrm{CCl}(\text { mean } \pm \mathrm{SD}) \\
\text { Hypertension }(\mathrm{n}, \%) \\
\text { Diabetes mellitus }(\mathrm{n}, \%) \\
\text { Chronic renal disease/ } \\
\text { failure }(n, \%)\end{array}$ & $\begin{array}{l}2.84 \pm 2 \\
34(41) \\
21(25) \\
12(15)\end{array}$ & $\begin{array}{l}3.15 \pm 3 \\
30(44) \\
25(37) \\
17(25)\end{array}$ & $\begin{array}{l}0.053 \\
0.696 \\
0.128 \\
0.102\end{array}$ \\
\hline $\begin{array}{l}\text { Congestive heart failure } \\
(n, \%)\end{array}$ & 0 & $8(11)$ & 0.715 \\
\hline $\begin{array}{l}\text { Coronary artery disease } \\
(n, \%)\end{array}$ & $26(31)$ & $15(22)$ & 0.203 \\
\hline $\operatorname{COPD}(n, \%)$ & $13(16)$ & $9(13)$ & 0.674 \\
\hline Asthma $(n, \%)$ & $5(6)$ & $9(13)$ & 0.128 \\
\hline Cancer $(n, \%)$ & $5(6)$ & $10(14)$ & 0.076 \\
\hline Immunosuppression $(n, \%)$ & $6(7)$ & $8812)$ & 0.339 \\
\hline $\begin{array}{l}\text { Time to initiation of } \\
\text { treatment (days), median } \\
\text { (IQR) }\end{array}$ & $6.6(3)$ & $5(4)$ & 0.135 \\
\hline WBC $\left(/ \mathrm{mm}^{3}\right)$, median (IQR) & $5150(4400)$ & $5600(3100)$ & 0.033 \\
\hline $\begin{array}{l}\text { Lymphocyte }\left(/ \mathrm{mm}^{3}\right) \text {, } \\
\text { median (IOR) }\end{array}$ & 1050 (950) & $1100(1300)$ & 0.873 \\
\hline BUN (mg/dl), median (IQR) & $26(22)$ & $36(30)$ & 0.075 \\
\hline $\begin{array}{l}\text { Creatinine }(\mathrm{mg} / \mathrm{dl}), \text { median } \\
\text { (IQR) }\end{array}$ & $0.7(0.3)$ & $0.89(0.76)$ & 0.159 \\
\hline AST (IU/L), median (IOR) & $33(24.3)$ & $34(28)$ & 0.410 \\
\hline ALT (IU/L), median (IOR) & $26(17.5)$ & $30(29)$ & 0.845 \\
\hline CRP (mg/L), median (IQR) & $41.5(66)$ & $31.3(80)$ & 0.192 \\
\hline Procalcitonin (ng/L) & $0.1(0.25)$ & $0.35(0.41)$ & 0.004 \\
\hline Ferritin $(\mu \mathrm{g} / \mathrm{L})$ & 409 (627.5) & $320(247)$ & 0.126 \\
\hline D-dimer $(\mu \mathrm{g} / \mathrm{L})$ & $1730(1310)$ & $1520(1470)$ & 0.087 \\
\hline LDH (IU/L), median (IOR) & $235(314)$ & $346(228)$ & 0.001 \\
\hline $\begin{array}{l}\text { Creatinine kinase (IU/L) } \\
\text { median (IQR) }\end{array}$ & $200(125)$ & 205 (132) & 0.945 \\
\hline $\begin{array}{l}\mathrm{O}_{2} \text { saturation (in ambient } \\
\text { air) }(\%)\end{array}$ & $92(4.25)$ & $87(6)$ & 0.024 \\
\hline ICU admission & $23(28)$ & $42(62)$ & 0.0001 \\
\hline $\begin{array}{l}\text { Secondary bacterial } \\
\text { infection }\end{array}$ & $1^{\mathrm{a}}(0.1)$ & $4^{b}(0.5)$ & 0.06 \\
\hline 14-day survival $(n, \%)$ & $69(83)$ & $51(75)$ & 0.218 \\
\hline 28 -day survival $(n, \%)$ & $64(77)$ & $44(65)$ & 0.093 \\
\hline $\begin{array}{l}\text { Median hospital stay } \\
\text { (days) } \\
\text { In-hospital crude } \\
\text { mortality }\end{array}$ & $\begin{array}{l}10(5) \\
19(23)\end{array}$ & $\begin{array}{l}16(12) \\
24(35)\end{array}$ & $\begin{array}{l}0.0001 \\
0.062\end{array}$ \\
\hline \multicolumn{4}{|c|}{$\begin{array}{l}\text { CCI: Charlson Comorbidity Index, COPD: Chronic obstructive pulmonary disease, WBC: } \\
\text { White blood cell count, BUN: Blood urea nitrogen, AST: Aspartate aminotransferase, } \\
\text { ALT: Alanine aminotransferase, IOR: Interquartile range, CRP: C-reactive protein, LDH: } \\
\text { Lactate dehydrogenase, LMWH: Low-molecular-weight heparin, a: Pneumonia, b: } 3 \\
\text { pneumonia, } 1 \text { urinary tract infecion }\end{array}$} \\
\hline
\end{tabular}

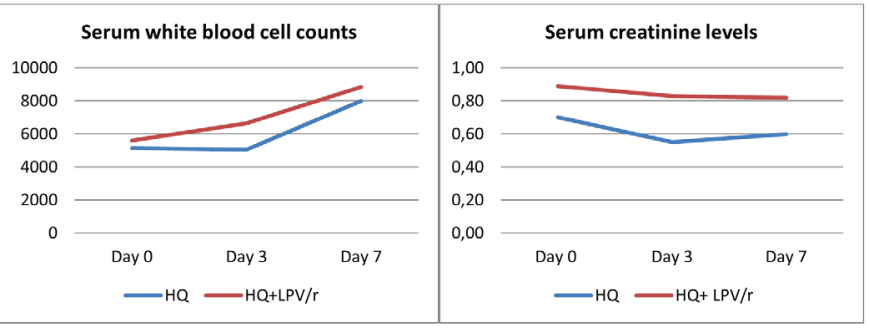

Figure 1. Comparison of serum white blood cell counts and creatinine levels on day 0,3 and 7 between hydroxychloroquine monotherapy and hydroxychloroquine plus lopinavir-ritonavir combination groups

HO: Hydroxychloroquine, Lpv/r: Lopinavir-ritonavir

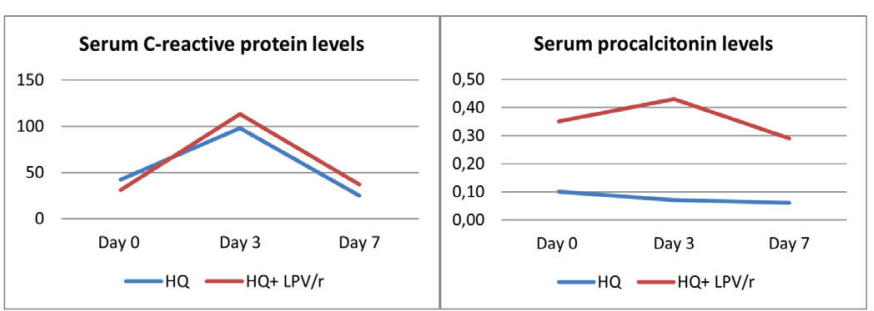

Figure 2. Comparison of serum C-reactive protein (A) and serum procalcitonin levels (B) on day 0,3 and 7 between hydroxychloroquine monotherapy and hydroxychloroquine plus lopinavir-ritonavir combination groups

HQ: Hydroxychloroquine, Lpv/r: Lopinavir-ritonavir

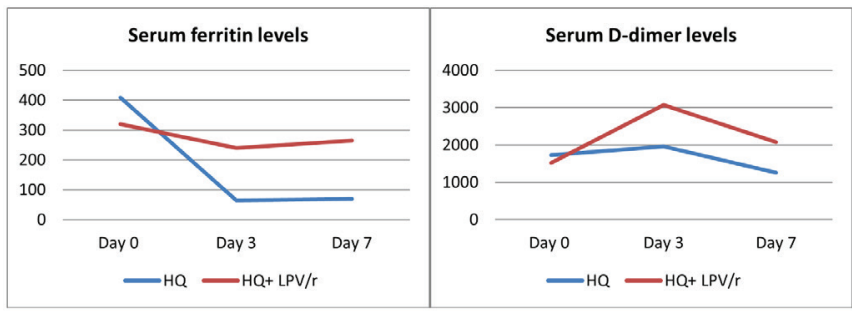

Figure 3. Comparison of serum ferritin $(A)$ and serum D-dimer levels (B) on day 0,3 and 7 between hydroxychloroquine monotherapy and hydroxychloroquine plus lopinavir-ritonavir combination groups

HQ: Hydroxychloroquine, Lpv/r: Lopinavir-ritonavir

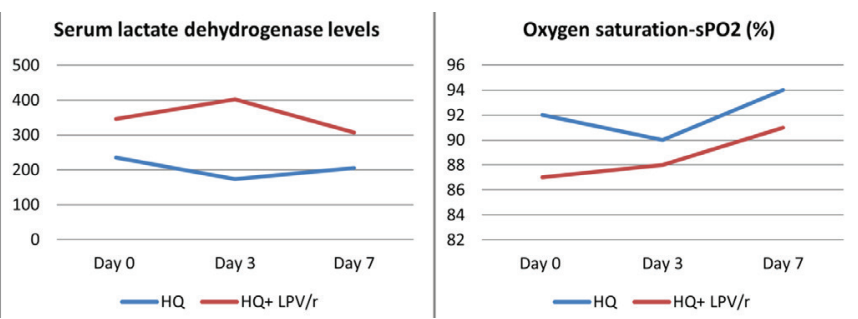

Figure 4. Comparison of serum lactate dehydrogenase levels (A) and oxygen saturation (B) on day 0,3 and 7 between hydroxychloroquine monotherapy and hydroxychloroquine plus lopinavir-ritonavir combination groups

HQ: Hydroxychloroquine, Lpv/r: Lopinavir-ritonavir 
therapy group, 39 patients (57\%) developed complications: 4 PTE, 21 hepatitis, 9 acute renal failure, 3 secondary bacterial pneumonia, 1 catheter-associated urinary tract infection, 2 cytokine release syndrome, 1 myocarditis, 1 acute respiratory distress syndrome (ARDS). Secondary bacterial infections were treated with effective antibacterial drugs. In-hospital crude mortality rates in the standard-care group and the combination therapy group were $23 \%$ and $35 \%$, respectively. In univariate analysis, age, hypertension, DM, chronic obstructive pulmonary disease (COPD), CCl, and ICU stay were the variables predicting 14-day mortality in the Kaplan-Meier log-rank test and Cox proportional-Hazards model (Table 2). In multivariate analysis, $\mathrm{CCl}$ and ICU stay were the independent predictors of 28-day mortality (Table 3). Cumulative survival rates of the patients in two different treatment groups are shown in Figure 5.

\section{Discussion}

The main purpose of our study was to compare the clinical efficacy of $\mathrm{HO}$ monotherapy and $\mathrm{HO}$ plus Lpv/r combination therapy. Lopinavir/r is readily available in many countries, including ours, and its effectiveness against SARS-CoV-2 and MERS-CoV-2 has been demonstrated ${ }^{[1,21]}$. It has also been used in combination with other antiviral drugs in SARS and MERS-CoV-2 infections ${ }^{[11,21,22]}$. It was suggested that the $L p v / r$ concentration necessary to inhibit pulmonary SARS-CoV-2 replication might be higher than the serum level obtained by the usual $L p v / r$ dose ${ }^{[23,24]}$. The World Health Organization recommends " $\mathrm{HO}$ and $\mathrm{Lpv} / \mathrm{r}$ not be administered as treatment or prophylaxis for COVID-19, outside of the context of clinical trials" in the interim guidance published on May 27, 2020 $0^{[25]}$

Our national guideline published by the Scientific Committee of the Ministry of Health recommends $\mathrm{HO}$ and/or favipravir in the treatment of COVID-19, and Lpv/r in pregnant patients with moderate to severe COVID-19, in the latest version, dated October $8,2020^{[26]}$.

The mean age of our patients was 61 years, 2/3 were male, and hypertension and DM were the most common comorbid diseases,

Table 2. Univariate analysis of the risk factors predicting 14-day and 28-day mortality among patients with SARS-CoV-2 pneumonia, before and after propensity score matching

\begin{tabular}{|c|c|c|c|c|c|c|c|c|}
\hline & \multicolumn{4}{|c|}{ Before PSM } & \multicolumn{4}{|c|}{ After PSM } \\
\hline & $\begin{array}{l}\text { 14-day } \\
\text { mortality } \\
\text { HR }(95 \% \mathrm{CI})\end{array}$ & $p$ value & $\begin{array}{l}\text { 28-day mortality } \\
\text { HR }(95 \% \mathrm{Cl})\end{array}$ & $p$ value & $\begin{array}{l}\text { 14-day mortality } \\
\text { HR (95\% CI) }\end{array}$ & $p$ value & $\begin{array}{l}\text { 28-day } \\
\text { mortality } \\
\text { HR }(95 \% \mathrm{CI})\end{array}$ & $p$ value \\
\hline Age & $1.06(1.02-1.06)$ & 0.002 & $0.96(0.92-0.98)$ & 0.37 & $1.01(0.9-1.04)$ & 0.001 & $0.71(0.69-0.88)$ & 0.32 \\
\hline Gender & $0.87(0.43-0.96)$ & 0.35 & $0.9(0.81-0.98)$ & 0.48 & $0.51(0.12-0.82)$ & 0.67 & $0.95(0.3-1.6)$ & 0.94 \\
\hline Hypertension & $1.62(1.3-1.92)$ & 0.01 & $1.53(1.26-1.98)$ & 0.14 & $1.02(1.01-1.73)$ & 0.01 & $1.53(1.1-1.92)$ & 0.24 \\
\hline COPD & $1.21(1.11-5.40)$ & 0.023 & $1.1(0.35-3.4)$ & 0.86 & $1.2(1.02-2.4)$ & 0.012 & $1.10(0.35-3.40)$ & 0.73 \\
\hline $\mathrm{CCl}$ & $0.75(0.58-0.97)$ & 0.03 & $0.75(0.58-0.97)$ & 0.03 & $0.62(0.53-0.86)$ & 0.004 & $0.75(0.58-0.97)$ & 0.03 \\
\hline $\begin{array}{l}\mathrm{O}_{2} \text { saturation (in } \\
\text { ambient air) }\end{array}$ & $2.1(2.05-6.2)$ & 0.02 & $2.6(1.9-3.8)$ & 0.002 & $2.9(1.56-8.2)$ & 0.01 & $3.2(2.9-4.9)$ & 0.02 \\
\hline ICU stay & $1.4(1.23-1.53)$ & $<0.0001$ & $1.5(1.39-1.76)$ & $<0.0001$ & $1.6(1.33-1.48)$ & $<0.0001$ & $1.5(1.39-1.76)$ & $<0.0001$ \\
\hline
\end{tabular}

Kaplan-Meier log-rank test and Cox proportional-hazards model, HR: Hazard ratio.

CCI: Charlson Comorbidity Index, COPD: Chronic obstructive pulmonary disease, ICU: Intensive care unit, PSM: Propensity score matching, Cl: Confidence interval

Table 3. Factors predicting 14-day and 28-day mortality before and after propensity score matching (PSM)-(Multivariate stepwise Cox regression analysis)

\begin{tabular}{|c|c|c|c|c|c|c|c|c|}
\hline & \multicolumn{4}{|c|}{ Before PSM } & \multicolumn{4}{|c|}{ After PSM } \\
\hline & $\begin{array}{l}\text { 14-day } \\
\text { mortality HR } \\
(95 \% \mathrm{Cl})\end{array}$ & $p$ value & $\begin{array}{l}\text { 28-day } \\
\text { mortality HR } \\
(95 \% \text { Cl) }\end{array}$ & $p$ value & $\begin{array}{l}\text { 14-day mortality } \\
\mathrm{HR}(95 \% \mathrm{CI})\end{array}$ & $p$ value & $\begin{array}{l}\text { 28-day } \\
\text { mortality } \\
\text { HR }(95 \% \mathrm{CI})\end{array}$ & $p$ value \\
\hline $\mathrm{CCl}$ & $0.75(0.58-0.97)$ & 0.003 & $0.85(0.43-0.9)$ & 0.03 & $0.67(0.53-0.87)$ & 0.002 & $0.7(0.6-0.9)$ & 0.02 \\
\hline ICU stay & $1.4(1.23-1.53)$ & $<0.0001$ & $1.5(1.39-1.76)$ & $<0.0001$ & $1.3(1.03-1.46)$ & $<0.0001$ & $1.5(1.39-1.64)$ & $<0.0001$ \\
\hline Combination therapy & $1.56(1.32-1.91)$ & 0.36 & $1.49(1.22-1.65)$ & 0.52 & $1.46(1.3-1.71)$ & 0.41 & $1.39(1.2-1.55)$ & 0.62 \\
\hline
\end{tabular}

Kaplan-Meier log-rank test and Cox proportional-hazards model, HR: Hazard Ratio 


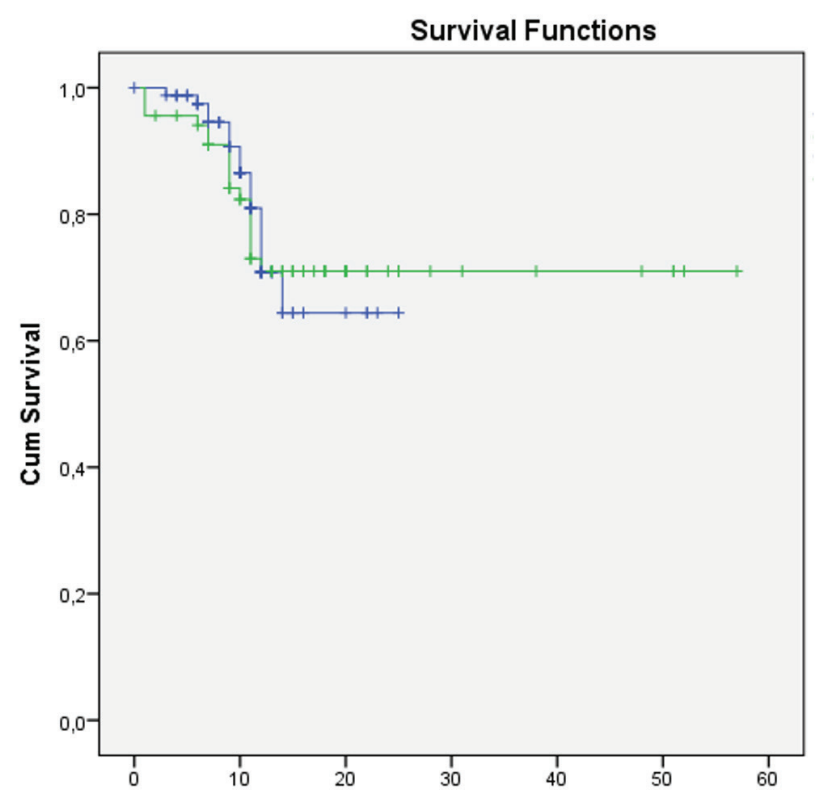

Figure 5. Cumulative survival of patients in two different treatment groups (blue line: monotherapy group, green line: combination therapy group)

similar to the findings in 393 patients reported by Goyal et al. ${ }^{[27]}$. Sixteen percent of patients had chronic renal disease, and $2.6 \%$ had chronic renal failure.

Cao et al. ${ }^{[16]}$ conducted a randomized, controlled, open-label trial for Lpv/r including 199 severe COVID-19 patients. They found no benefit of $L p v / r$ beyond standard care. The median time between the onset of symptoms and initiation of therapy was 13 days in that trial, while it was nearly six days (one week earlier) in our study. Antiviral drugs are most effective against coronaviruses when they are administered early ${ }^{[28]}$, since the rate of viral replication is high in the earlier stages of COVID-19, but systemic hyperinflammation may ensue in later stages ${ }^{[30]}$. Lopinavir/r given within 12 days of symptoms may not be as effective as when given earlier in the disease course. The mean duration of hospital stay was six days longer in the combination group in our study. In the course of a pandemic, the length of hospital stay for each patient is important because there may be a shortage of hospital beds, mechanical ventilators, etc. More than half $(62 \%)$ of the patients in the combination therapy group were followed-up in the ICUs. Similarly, leukocyte counts, creatinine, CRP, PCT, LDH, ferritin, and D-dimer levels on the $3^{\text {rd }}$ and $7^{\text {th }}$ days of therapy were significantly higher, but oxygen saturation was lower in the combination therapy group. Those laboratory parameters have been reported to be prognostic factors of disease severity and worse outcomes ${ }^{[30]}$. Moreover, in a systematic literature review and meta-analysis including a total of 3,027 patients with COVID-19, WBC, aspartate aminotransferase (AST), creatinine, PCT, LDH, and D-dimer were reported as markers of disease progression ${ }^{[31]}$.
Our national guidelines recommend the administration of $L p v / r$ in more severe patients, which might be one of the underlying reasons for the increased laboratory values and length of hospital stay in that group. Clinically more severe patients in the combination therapy group required more oxygen support, as expected. Regarding clinical improvement, Lpv/r had no advantage beyond the standard of care. In the trial conducted by Cao et al. ${ }^{[16]}$, the inclusion criteria referred to severely ill patients with COVID-19. However, in our study, all patients with COVID-19 pneumonia were included. Ye et al. ${ }^{[32]}$ conducted a study including 47 COVID-19 patients and compared Lpv/r combined with adjuvant medicine to only adjuvant medicine. In contrast to our results, the body temperature, WBC, lymphocyte and CRP, alanine aminotransferase, and AST decreased faster in the combination group.

In our study, although patients in the combined therapy group required more oxygen support and had worse laboratory results, the 14-day and 28-day mortality rates were not statistically significantly different between the two treatment groups. In the Lpv/r clinical trial, the median time to clinical improvement was not significantly different, and the 28-day mortality rate was similar in both groups. Although statistically non-significant, 28-day mortality was 5.8\% lower in the Lpv/r group. Intentionto-treat analysis excluded three patients with early death (in the first 24 hours of therapy) and then clinical improvement was one day shorter in the Lpv/r group. The overall mortality rate was $22 \%$ in that trial ${ }^{[16]}$. In our study, the ICU admission rate in the monotherapy group was $28 \%$ with an overall mortality of $23 \%$. In the combination therapy group, the ICU admission rate and overall mortality were $62 \%$ and $35 \%$, respectively. Overall, the mortality rate in critically ill patients in the ICU in our study was less than that (62\%) reported in the study conducted by Yang et al. ${ }^{[33]}$, but more than that (31\%) reported by Auld et al. ${ }^{[34]}$. Despite a nearly 2 -fold greater ICU follow-up requirement in the combination therapy group, only half of the patients in the ICU died of COVID-19. Twice as many complications were observed in the combination group, which was comprised of more critically ill patients.

Only six patients in each group had adverse events in our study. Serious adverse events and respiratory failure or ARDS occurred more commonly in the standard-care group (32\% vs. $20 \%$ and $27 \%$ vs. $13 \%$, respectively) in the clinical trial by Cao et al. ${ }^{[16]}$. In our study, age, hypertension, DM, chronic obstructive pulmonary disease, $\mathrm{CCl}$, and ICU stay were the variables predicting 14-day mortality. These results were similar to findings in a systematic review and meta-analysis on that subject ${ }^{[29]}$. Charlson Comorbidity Index and ICU admission were the independent predictors of 28-day mortality in our study. 


\section{Study Limitations}

The major limitations of our study were its retrospective design and the heterogenity of the patient population regarding disease severity, as combination therapy were provided for more severe patients. Moreover, there were more critically ill patients who had been admitted to the ICU in the combination therapy group, as our national treatment guidelines recommend combination therapy to severely ill COVID-19 patients. Further clinical studies are necessary to determine whether earlier and extended administration of antiviral drugs may improve clinical outcomes in patients with COVID-19 pneumonia. The clinical impact of our study is that we no longer prefer to use Lpv/r as there is no additional benefit to it.

\section{Conclusion}

In conclusion, there were no statistically significant differences between the two treatment groups regarding 14-day and 28day mortality. As combination therapy with Lpv/r and $\mathrm{HO}$ was administered to more severe patients requiring more oxygen support, it did not seem to provide any benefit compared with HO monotherapy regarding mortality. Charlson Comorbidity Index and ICU stay were independent predictors of 28-day mortality.

\section{Ethics}

Ethics Committee Approval: The study were approved by the University of Health Sciences Turkey, Kartal Dr. Lütfi Kırdar City Hospital of Clinical Research Ethics Committee (protocol number: 2020/514/177/2, date: 13.05.2020).

Informed Consent: Retrospective study.

Peer-review: Externally peer-reviewed.

\section{Authorship Contributions}

Concept: A.B., S.T., H.B., Design: A.B., S.T., H.B., N.B., Data Collection or Processing: A.B., S.T., H.B., Analysis or Interpretation: A.B., H.B., Ç.A.K., Literature Search: A.B., S.T., H.B., Writing: A.B., N.B.

Conflict of Interest: No conflict of interest was declared by the authors.

Financial Disclosure: The authors declared that this study received no financial support.

\section{References}

1. Worldometer. Last accessed date: 02.03.2021. Available from: https://www. worldometers.info/coronavirus/?utm_campaign=homeAdvegas1?

2. Li G, De Clercq E. Therapeutic options for the 2019 novel coronavirus (2019nCoV). Nat Rev Drug Discov. 2020;19:149-50.

3. Şimşek Yavuz S, Ünal S. Antiviral treatment of COVID-19. Turk J Med Sci. 2020;50:611-9.
4. Alpern JD, Gertner E. Off-Label Therapies for COVID-19-Are We All In This Together? Clin Pharmacol Ther. 2020;108:182-4.

5. Lu CC, Chen MY, Lee WS, Chang YL. Potential therapeutic agents against COVID-19: What we know so far. J Chin Med Assoc. 2020;83:534-6.

6. Zhu S, Guo X, Geary K, Zhang D. Emerging Therapeutic Strategies for COVID-19 patients. Discoveries (Craiova). 2020;8:105.

7. Jean SS, Lee PI, Hsueh PR. Treatment options for COVID-19: The reality and challenges. J Microbiol Immunol Infect. 2020;53:436-43.

8. Yao X, Ye F, Zhang M, Cui C, Huang B, Niu P, Liu X, Zhao L, Dong E, Song C, Zhan S, Lu R, Li H, Tan W, Liu D. In Vitro Antiviral Activity and Projection of Optimized Dosing Design of Hydroxychloroquine for the Treatment of Severe Acute Respiratory Syndrome Coronavirus 2 (SARS-CoV-2). Clin Infect Dis. 2020;71:732-9.

9. Nutho $B$, Mahalapbutr $P_{1}$ Hengphasatporn $K$, Pattaranggoon NC, Simanon $N$, Shigeta $Y$, Hannongbua $S$, Rungrotmongkol T. Why Are Lopinavir and Ritonavir Effective against the Newly Emerged Coronavirus 2019? Atomistic Insights into the Inhibitory Mechanisms. Biochemistry. 2020;59:1769-79.

10. Chen $F$, Chan KH, Jiang Y, Kao RY, Lu HT, Fan KW, Cheng VC, Tsui WH, Hung $I F$, Lee TS, Guan Y, Peiris JS, Yuen KY. In vitro susceptibility of 10 clinical isolates of SARS coronavirus to selected antiviral compounds. J Clin Virol. 2004;31:69-75.

11. Chu CM, Cheng VC, Hung IF, Wong MM, Chan KH, Chan KS, Kao RY, Poon LL, Wong $C L$, Guan Y, Peiris JS, Yuen KY; HKU/UCH SARS Study Group. Role of lopinavir/ritonavir in the treatment of SARS: initial virological and clinical findings. Thorax. 2004;59:252-6.

12. de Wilde AH, Jochmans D, Posthuma CC, Zevenhoven-Dobbe JC, van Nieuwkoop S, Bestebroer TM, van den Hoogen BG, Neyts J, Snijder EJ. Screening of an FDA-approved compound library identifies four smallmolecule inhibitors of Middle East respiratory syndrome coronavirus replication in cell culture. Antimicrob Agents Chemother. 2014;58:4875-84.

13. Chan JF, Yao Y, Yeung ML, Deng W, Bao L, Jia L, Li F, Xiao C, Gao H, Yu $P_{1}$ Cai JP, Chu H, Zhou J, Chen H, Qin C, Yuen KY. Treatment With Lopinavir/ Ritonavir or Interferon- $\beta 1 \mathrm{~b}$ Improves Outcome of MERS-CoV Infection in a Nonhuman Primate Model of Common Marmoset. J Infect Dis. 2015;212:1904-13.

14. Groneberg DA, Poutanen SM, Low DE, Lode H, Welte T, Zabel P. Treatment and vaccines for severe acute respiratory syndrome. Lancet Infect Dis. 2005;5:147-55.

15. Cheng CY, Lee YL, Chen CP, Lin YC, Liu CE, Liao CH, Cheng SH. Lopinavir/ ritonavir did not shorten the duration of SARS CoV-2 shedding in patients with mild pneumonia in Taiwan. J Microbiol Immunol Infect. 2020;53:48892.

16. Cao B, Wang $Y$, Wen $D$, Liu W, Wang J, Fan G, Ruan L, Song B, Cai $Y$, Wei $M$, Li X, Xia J, Chen N, Xiang J, Yu T, Bai T, Xie X, Zhang L, Li C, Yuan Y, Chen H, Li H, Huang H, Tu S, Gong F, Liu Y, Wei Y, Dong C, Zhou F, Gu X, Xu J, Liu Z, Zhang Y, Li H, Shang L, Wang K, Li K, Zhou X, Dong X, Qu Z, Lu S, Hu X, Ruan S, Luo S, Wu J, Peng L, Cheng F, Pan L, Zou J, Jia C, Wang J, Liu X, Wang S, Wu X, Ge Q, He J, Zhan H, Qiu F, Guo L, Huang C, Jaki T, Hayden FG, Horby PW, Zhang D, Wang C. A Trial of Lopinavir-Ritonavir in Adults Hospitalized with Severe Covid-19. N Engl J Med. 2020;382:1787-99.

17. National Health Commission of the People's Republic of China. Notice on printing and distributing the diagnosis and treatment plan of pneumonia with new coronavirus infection (trial version 3) 2020.

18. Bhimraj A, Morgan RL, Shumaker AH, Lavergne $V$, Baden $L$, Cheng VC, Edwards KM, Gandhi R, Muller WJ, O'Horo JC, Shoham S, Murad MH, Mustafa RA, Sultan S, Falck-Ytter Y. Infectious Diseases Society of America Guidelines on the Treatment and Management of Patients with COVID-19. Clin Infect Dis. 2020;27:478.

19. Republic of Turkey, Ministery of Health COVID-19 Guidelines (25.02.2020, 25.03.2020 and 02.04.2020 dated versions) 2020; Available from: https:// covid19bilgi.saglik.gov.tr/tr/covid-19-rehberi.html 
20. Charlson ME, Pompei P, Ales KL, MacKenzie CR. A new method of classifying prognostic comorbidity in longitudinal studies: development and validation. J Chronic Dis. 1987;40:373-83.

21. Arabi YM, Alothman A, Balkhy HH, Al-Dawood A, AlJohani $\mathrm{S}$, Al Harbi S, Kojan S, Al Jeraisy M, Deeb AM, Assiri AM, Al-Hameed F, Al Saedi A, Mandourah Y, Almekhlafi GA, Sherbeeni NM, Elzein FE, Memon J, Taha Y, Almotairi A, Maghrabi KA, Qushmaq I, Al Bshabshe A, Kharaba A, Shalhoub $\mathrm{S}$, Jose J, Fowler RA, Hayden FG, Hussein MA; And the MIRACLE trial group. Treatment of Middle East Respiratory Syndrome with a combination of lopinavir-ritonavir and interferon- $\beta 1 \mathrm{~b}$ (MIRACLE trial): study protocol for a randomized controlled trial. Trials. 2018;19:81.

22. Chan KS, Lai ST, Chu CM, Tsui E, Tam CY, Wong MM, Tse MW, Que TL, Peiris JS, Sung J, Wong VC, Yuen KY. Treatment of severe acute respiratory syndrome with lopinavir/ritonavir: a multicentre retrospective matched cohort study. Hong Kong Med J. 2003;9:399-406.

23. Sheahan TP, Sims AC, Leist SR, Schäfer $A$, Won J, Brown AJ, Montgomery SA, Hogg A, Babusis D, Clarke MO, Spahn JE, Bauer L, Sellers S, Porter D, Feng JY, Cihlar T, Jordan R, Denison MR, Baric RS. Comparative therapeutic efficacy of remdesivir and combination lopinavir, ritonavir, and interferon beta against MERS-CoV. Nat Commun. 2020;11:222.

24. Baden LR, Rubin EJ. Covid-19 - The Search for Effective Therapy. N Engl J Med. 2020;382:1851-2.

25. World Health Organization (WHO). Last Accessed date: 27.05.2020. Available from: https://apps.who.int/iris/handle/10665/332196

26. T.C. Sağlık Bakanlığı COVID-19 Bilgilendirme Platformu. Last Accessed date: 08.10.2020. Available from: https://covid19.saglik.gov.tr/

27. Goyal P, Choi JJ, Pinheiro LC, Schenck EJ, Chen R, Jabri A, Satlin MJ, Campion TR Jr, Nahid M, Ringel JB, Hoffman KL, Alshak MN, Li HA, Wehmeyer GT, Rajan M, Reshetnyak E, Hupert N, Horn EM, Martinez FJ, Gulick RM, Safford
MM. Clinical Characteristics of Covid-19 in New York City. N Engl J Med. 2020;382:2372-4.

28. de Wit E, van Doremalen N, Falzarano D, Munster VJ. SARS and MERS: recent insights into emerging coronaviruses. Nat Rev Microbiol. 2016;14:523-34.

29. Siddiqi HK, Mehra MR. COVID-19 illness in native and immunosuppressed states: A clinical-therapeutic staging proposal. J Heart Lung Transplant. 2020;39:405-7.

30. Sun Y, Dong Y, Wang L, Xie H, Li B, Chang C, Wang FS. Characteristics and prognostic factors of disease severity in patients with COVID-19: The Beijing experience. J Autoimmun. 2020;112:102473.

31. Zheng Z, Peng F, Xu B, Zhao J, Liu H, Peng J, Li $Q$, Jiang C, Zhou Y, Liu $S$, Ye C, Zhang P, Xing Y, Guo H, Tang W. Risk factors of critical \& mortal COVID-19 cases: A systematic literature review and meta-analysis. J Infect. 2020;81:16-25.

32. Ye XT, Luo YL, Xia SC, Sun QF, Ding JG, Zhou Y, Chen W, Wang XF, Zhang WW, Du WJ, Ruan ZW, Hong L. Clinical efficacy of lopinavir/ritonavir in the treatment of Coronavirus disease 2019. Eur Rev Med Pharmacol Sci. 2020;24:3390-6.

33. Yang $X, Y u Y, X u$ J, Shu $H$, Xia J, Liu $H, W u Y$, Zhang $L, Y u Z$, Fang $M, Y u$ $T$, Wang $Y$, Pan $S$, Zou $X$, Yuan $S$, Shang $Y$. Clinical course and outcomes of critically ill patients with SARS-CoV-2 pneumonia in Wuhan, China: a single-centered, retrospective, observational study. Lancet Respir Med. 2020;8:475-81.

34. Auld SC, Caridi-Scheible M, Blum JM, Robichaux C, Kraft C, Jacob JT, Jabaley CS, Carpenter D, Kaplow R, Hernandez-Romieu AC, Adelman MW, Martin GS, Coopersmith CM, Murphy DJ; Emory COVID-19 Quality and Clinical Research Collaborative. ICU and Ventilator Mortality Among Critically III Adults With Coronavirus Disease 2019. Crit Care Med. 2020;48:799-804. 